\title{
The Right of Access to Health Care for Migrants in the Republic of North Macedonia - Barriers and Challenges
}

\author{
Angelka Jankulovska $^{1^{*}} \quad$ Fimka Tozija $^{2,3}$ \\ 1.Higher Medical School, St Kliment Ohridski - University, Bitola, Republic of North Macedonia \\ 2.Institute for Public Health of the Republic of North Macedonia \\ 3.Medical Faculty, University "Ss. Cyril and Methodius", Skopje, Republic of North Macedonia
}

\begin{abstract}
Introduction: In recent years hundreds of thousands of refugees and migrants who have left their homes in order to reach the EU member states have transited through The Republic of North Macedonia (RNM). The dynamics of the refugee crisis in this period continually tested the readiness of the state to fully respect the guarantees of basic human rights, cultural and social differences, as well as respect for human dignity. The R. of North Macedonia throughout the crisis has remained a country of transit, not a target destination for refugees and migrants. The increasing number of migrants makes much more pressure on health systems in countries. Access to health services is one of the most basic issues, because high-quality care and health care is not effective if people don 't have access to it.Purpose of the paper is to represent the right and access to health care for migrants in the Republic of Northern Macedonia, the restriction of the health system, as well as the policies for improving the availability of health services for migrants.Material and Methods: In this paper are used, a public health approach, an infromatic-analytical method and sinteses evidence, and a review of the existing legislation, strategic documents and other documents. The materials whish were used are electronic databases such as PubMed, HINARI, EBSCO, Google Scholar, Scopus, and special search strategies for each keyword database based on inclusion criteria. For a detailed and specific view, were used reports from the International Organization for Migration (IOM)Results and Discussion: With an overall assessment of MIPEX 38/100, the country's policies are barely conducive to social integration. These policies are the result below the European average and an average slightly better than other countries in the region. Migrants lack targeted state support to find the right job, improve their children's education or benefit from consultative bodies. After the adoption of the National Strategy for the Integration of Refugees and Migrants in 2017, as one of the key documents of the Ministry of Labor and Social Policy that regulates the country's policy in dealing with affirmed refugees and foreigners on its territory, in 2018, the Action plan for the integration of refugees and foreigners 2017-2027.

Migrants and refugees have multiple barriers to access to health care, as well as discrimination in access to the asylum procedure - which indirectly affects the exercise of healthcare rights.Conclusion: Despite the efforts made to give a quick response to the migration-refugee crisis, the Republic of North Macedonia needs further improvement of the respect and protection of the human rights of migrants and refugees. Health system reforms are needed in order to provide a faster and more efficient response to the needs of vulnerable groups who are staying and transiting through the Republic of North Macedonia.
\end{abstract}

Keywords: migrants, refugees, health care, health care system, Republic of North Macedonia

DOI: $10.7176 / \mathrm{JHMN} / 70-03$

Publication date: January $31^{\text {st }} 2020$

\section{Introduction}

In recent years, hundreds of thousands of refugees and migrants have transit through the Republic of North Macedonia (RNM) in order to reach the European Member States Union (EU). The dynamics of the refugee crisis during this period were continuously tested the readiness of the state to fully respect the guarantees of basic human beings rights, cultural and social differences, and respect for human dignity.

The RSM, during the whole crisis, remained a transit country, not a target destination for refugees and migrants. (1)

\subsection{Migrant crisis and transit and reception centers}

Established transit centers in Vinojug, Gevgelija (TC Vinojug) and Tabanovce, Kumanovo (TC Tabanovce) continued to operate on the old principles. Camp coordination remains in the hands of the Center crisis management, and representatives from the relevant institutions are still present the Ministry of Interior (MOI), the Ministry of Labor and Social Policies (MLSP) and the Ministry of Health (MOH). Besides the state institutions, the camp also includes civil society organizations (domestic and international). TC Vinojug is a closed camp, the refugees and migrants which residing there can't leave the camp without prior notice consent from competent institutions and without escort (from MLSP or Red Cross) during the exit. Unlike them, refugees and migrants accommodated in TC Tabanovce have the opportunity to leave the camp, for their own needs anytime and unaccompanied by officials. (2) 
At the beginning of 2019, about 70 refugees were housed at TC Vinojug (14 January 2019) with different backgrounds. In TC Tabanovce, due to openness, the number of refugees has fluctuated throughout the year. TC Tabanovce in 2018 continued with the selective omission policy of refugees, where the selection was based on uncertain criteria and without rules. (3) In doing so, there have been situations where they have resided longer refugees and migrants outside the center rather than inside.

Holding educational and recreational activities in the camps were completely left to civil and international organizations. It is important to note that the Ministry of Education at no point in the refugee crisis did not officially involve organizing educational classes for children staying in the centers, although access to education is one of their essentials guaranteed rights. (4) What is really lacking is institutional support and treatment of this vulnerable group. (5)

\subsection{Health problems}

When it is concluded that migrants have specific needs, it can be elucidated through two things, the first concerns service delivery, that is, essentially means that the distance between services and migrants should be reduced, with removing barriers to access and securing communication. (6) The second thing is to change attitudes about refugee health. When interest in the health of migrants first arose, there was a tendency to treat them as a specific type, it is determined that a new medical specialty is needed to deal with their problems, because diseases that they encountered are quite different from those of the majority population. (7) Extended expert knowledge is needed to deal with the effects of refugees traumatic experiences.

\section{Aims}

Aim of this paper is to illustrate the right and access to health care, of migrants (legal and undocumented and asylum seekers) in the Republic of North Macedonia. To illustrate the limitations of the health system for this special vulnerable category, as well as policies to improve the availability of health services for migrants.

\section{Materials and methods}

The paper employs a public-health, information-analytical approach method and method of synthesis evidence and desk review of existing legislation, strategic documents and other documents. As materials were used complex electronic databases such as PubMed, HINARI, EBSCO, Scopus where credible sources show the situation in the country for during the refugee crisis and after that as a transit country. Used separately search strategies for each keyword database based on inclusion criteria as of February 2019. In addition to searches in electronic databases, and reference lists of articles were reviewed advanced search queries via Google Scholar. For detailed and specific display, were used a reports of the International Organization for Migration (IOM) especially the MIPEX study, where several aspects are presented, which are very important for migrants and asylum seekers.

\section{Results and discussion}

\subsection{Public health challenges - Access and availability of health services}

The steady increase in the number of migrants made it much larger pressure on health systems in countries. Previous years were sent countless tutorials, recommendations, and brief guidelines, but few follow the basic medical procedure, establishing a thorough diagnosis before prescribing any medicine. (9) This stems from the extensive research on health policies that it has covers the whole of Europe. (10) Access to health services is one of the most basic issues, because high quality care and health care is not effective, if individuals do not have access to it. The approach consists of several elements, for a detailed explanation, it is necessary to separate them and to justify them individually.

(11) The right of health care not mean that care is free, what must be, is to be affordable and accessible. If you have to pay the full cost of treatment or again it must use a private health insurance policy, which is not regulated the state then considers that the right care is not provided. (12) The right to health services, including the right to health insurance is regulated by the Foreigners Law (13) and the Health Act insurance in the Republic of North of Macedonia (RNM) The Law on Foreigners regulates the conditions of entry, exit and residence of foreigners, as well as their rights and obligations. If foreigners have legal residence, they have same rights and obligations as well citizens of RNM. Special rights for vulnerable groups are available to children when they are works on immunization of children under 18. The health protection of asylum seekers is governed by the Law on International and temporary protection (14) and the Health Insurance Act. By this law there are three types of international protection: recognized refugees, persons under subsidiary protection and persons with temporary protection. By the same law, the applicants for right to asylum until a final decision $\mathrm{n}$ the recognition procedure, besides other rights they have a right of basic health services. (15)

Primary care was provided by The Red Cross, according to reports from the Red Cross, during 2018 transit centers and the surrounding regions reported a total of 14,958 first aid times and assists. In the centers, were 
present doctors appointed by the $\mathrm{MOH}$, which intervened when it needed. In the case of life-threatening, urgent situations medical intervention should be provided without documentation of the patient.

As the number of such cases is very small, no clear regulatory measures have yet been taken. They do not have access to the health system as nationals: they have private or full insurance pay for services at the place of use. Under the Foreigners law, for an illegal stay in the Republic of Macedonia is considered if: a foreigner enters the country without a permit, holds a valid and recognized travel document submitted with a visa or residence permit. Migrants who enter the country illegally are transferred to MIA Reception Center in Gazi Baba (Skopje). Costs for health services during their stay in this center covered by the Government through the Ministry of Interior. If migrant seek asylum, he move to Reception Center in Vizbegovo, where they have the same rights to health care as asylum seekers. During the reporting 384 persons were accommodated in the Reception Center for Foreigners (Gazi Baba) Asylum Seekers Center (Vizbegovo) 186 persons. If undocumented a migrant is not in the transit center and does not apply for asylum, he has no right to health care and should fully cover the cost of the service. The International Organization for Migration in Skopje was established in 1999 with aim to assist the country in implementing the Stabilization and Association Agreement; and association, with a particular emphasis on migration management. (16) Most research indicates that the current situation, in most countries are probably better off for asylum seekers than others categories of migrants. The situation for undocumented migrants is worse, they say in fact they are not fully informed about their rights and organization of health system. According to IOM Macedonia, there is absolutely no concession to the idea that migrants have special needs in every sense and according to the measures taken to achieve change, full implementation of the action is still lacking plans for dealing with migrants. What is emphasized is that it is urgently needed an action plan to improve the health policies of migrants in Macedonia,

With MIPEX's overall score of 38/100, the country's policies are barely there favorable for social integration. These policies are the result of the European one average and slightly better than other countries in the region (15). To the migrants lacks targeted state support to find the right thing to do improve the education of their children or benefit from consultative bodies. (17)

The IOM (International Organization for Migration) study measured the restrictive conditions of law, the scope of services covered and the exceptions which exist for vulnerable groups or conditions that are considered public health risks. At the same time, the IOM has been measuring the barriers to getting rights: tough procedures for gaining access to treatment or unclear rules subject to administrative or clinical discretion. This clarifies the first two components of the approach:

- Right to health care

- Administrative barriers to obtaining the right

- Lack of information on the health system

- Threat to be reported

- Language and cultural barriers

- Practical barriers

Preparation of the National Strategy for the Integration of Refugees and migrants in 2017 as one of the key documents of the Ministry of Labor and social policy that governs state policy in dealing with affirmed refugees and foreigners on its territory in 2018 was Action Plan for Integration of Refugees and Foreigners 2017-2027 prepared, divided on six different areas of action in line with the Strategy: system of integration, early integration, housing, education, employment and naturalization. Each activity in the action plan is foreseen within a specific timeframe with designated institution responsible for its implementation. (18) The inclusion of NGOs in the implementation would also mean monitoring of implementation of the action plan and assurance of its consistent implementation.

\subsection{Barriers}

Extensive research in this area has identified more barriers to access to health care, especially because attention is focused on describing problems for this category rather than finding solutions. What is crucial is to provide qualified interpreted services for patients with inappropriate language skills.

There is no official policy in this regard. (19) The process of local integration comprises three main elements. One is aimed at fortifying and retaining persons who received asylum in the national system of welfare and protection, who includes health services and social protection. The latter provides a developmental aspect integration through specially tailored projects to support self - support of asylum seekers by addressing their needs in the housing, employment, education and vocational training. The third Element offers legal assistance to help integrate refugees into the gain legal status in the country that enables their full integration into the new society: citizenship through naturalization or permanent residence. (20)

The Center for the Integration of Refugees and Workers plays a key role in achieving positive results, it was established in 2009 by MLSP and the United Nations High Commissioner for Refugees. Provided more than 6000 direct assistance interventions for refugee families participating in the process of local integration. The 
Integration Center works closely with government institutions and non-governmental organizations involved in security of different services. (21).

Following the events related to the refugee crisis during 2018 year, it can be concluded that with the increase in the movement of migrants and refugees through irregular roads, the refugee crisis must not be considered complete. The official number of refugees and migrants in the Republic of Macedonia is centers are relatively low, compared to the number of refugees and migrants moving along irregular roads. (22)

At the same time, there was a need for reforms in the health system in order to provide a faster and more efficient response to the needs of vulnerable groups who reside and transit through the Republic of Macedonia. The development of existing ones is also needed health facilities within the reception and transit centers at refugees and migrants. All these measures to transform the health system, will have no meaning without providing health professionals who are ready to respond to the challenges of enabling migration of culturally appropriate refugee patient oriented health services and migrants. (23)

Migrants and refugees face more barriers to access health care, as well as discrimination in access to recognition of the right to asylum - which indirectly affects the exercise of rights from health care.

\section{Conclusion}

Despite the efforts made to give a quick response to the migrant - refugee The crisis in the Republic of North Macedonia needs further improvement respect for and protection of the human rights of migrants and refugees. Required are reforming the health system to provide a faster and more efficient response to the needs of vulnerable groups residing and transit across the Republic of North Macedonia

\section{References}

1. Kolfinopoulou G., Kassiani L., Triantafyllou E., Epidemiological Surveillance in Points of Care for Refugees/Migrants: The 2016-2017 Experience in Greece. Athens 2018.

2. Мемети И., Посебен извештај за состојбите во Прифатниот транзитен центар,Табановце“. Скопје : Народен правобранител, Омбдусман, 2017.

3. Spiegel P., Douglas M., Cetron P., Definitions matter: migrants, immigrants, asylum seekers and refugees , Journal of Travel Medicine, Vol. 26, 2019

4. Abbas M, Aloudat T, Bartolomei J, Carballo M. ,Migrant and refugee populations: a public health and policy perspective on a continuing global crisis., Antimicrobial Resistance \& Infection Control, Vol. 7, 2018

5. Migrant Crisis in mediterranean. Available from: https:/www.coe.int/en/web/commissioner/-/crisis-in-themediterranean-europe-must-change-course Accessed on: 20.01.2019

6. David M., Tessema F , The unmet needs of refugees and internally displaced people.. 2018.

7. Bapolisi A., Crabtree K.,Jarolimova J., Assessment of attitudes and targeted educational needs for refugee care providers in a Ugandan hospital.. 9, s.l. : Int J Med Educ, 2018, Vol. 24, pp. 221-225.

8. Salami B, Salma J, Hegadoren K. Access and utilization of mental health services for immigrants and refugees: Perspectives of immigrant service providers. 2, s.1. : Mental Health Nursing, 2018, Vol. XXVII, pp. 152161.

9. Racaj M. Migrant Crisis, a Security Challenge for the Republic of Macedonia, Скопје 2017.

10. Jonzon R, Lindkvist P, Hurtig AK, Structural and procedural barriers to health assessment for asylum seekers and other migrants - an explorative survey in Sweden; BMC Health Serv Res, Vol. 18, 2018

11. Rurik I, Kolozsvári LR, Aarendonk D, Angelaki A, Ajdukovic D et al., Primary care of refugees and migrants. Lesson learnt from the EUR-HUMAN project. 2018 Vol. 159(35):(1414-1422),

12. Kang C, Tomkow L, Farrington R., Access to primary health care for asylum seekers and refugees: a qualitative study of service user experiences in the UK. British Journal of GeneralPractice, 2019.

13. ЗАКОН ЗА СТРАНЦИ , Службен весник на Република Северна Македонија бр. 35/2006, 66/2007, 117/2008, 92/2009, 156/2010, 158/2011, 84/2012, 13/2013, 147/2013, 148/2015 и 2017/2015 Available from: [http://www.mtsp.gov.mk] Accessed on: 28.12.2018

14. ЗАКОН ЗА АЗИЛ И ПРИВРЕМЕНА ЗАШТИТА, Службен весник на Република Северна Макеоднија бр. 49/203, 66/2007, 142/2008, 156/2009, 166/2012, 101/2015, 152/2015 и 55/2016. Available from :[www.pravdiko.mk] Accessed on: 15.01.2019

15. Tozija F, Memeti S. Migrant outbreak - a public health treat that needs immediate response and shared responsibility. Int J Health Sci Res. 2015; 5(9):512-520.

16. Apostolova, R. Of Refugees and Migrants: Stigma, Politics, and Boundary Work at the Borders of Europe. Available from: https://asaculturesection.org/2015/09/14/of-refugees-and-migrants-stigma-politics-andboundary-workat.

17. Grammatikopoulou MG, Theodoridis X, Poulimeneas D et all .,Malnutrition surveillance among refugee children living in reception centres in Greece: a pilot study,. International Health, London, 2019 Vol. XX.

18. WHO. Strategy and action plan for refugee and migrant health in the WHO European region. Available from: 
http://www.euro.who.int/_data/assets/pdf_file/0004/314725/66wd08e_Migrant Health Strategy

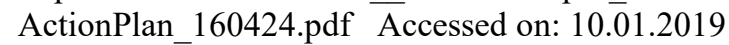

19. Longoria, Yessenia D ,.Population health of refugees in rural communities., Nursing menagment, 2018 Vol. 49(10), pp. 16-21.

20. Kristiansen M., Razum O., Aging and health among migrants in a European perspective, Public Health Reviews, 2016 pp. 20-37. Available from: https://doi.org/10.1186/s40985-016-0036-1

21. Kentikelenis A., Shriwise A., International organizations and migrant., Bio Med central, 2016.

22. Goodman S, Sirriyeh A. ,McMahon S., The evolving (re)categorisations of refugees..vol 27: Wiley, 2017.

23. Loomis AM, Berthold SM, Buckley T, ,Integrated Health Care and mHealth: A Model of Care for Refugees with Complex Health Conditions., Social Work in Public Health, 2019. 